\title{
Future directions in the treatment of patients with chronic hepatitis $\mathrm{C}$ virus infection
}

\author{
Robert G Gish MD
}

Robert G Gish. Future directions in the treatment of patients with chronic hepatitis $\mathrm{C}$ virus infection. Can J Gastroenterol 1999;13(1):57-62. Hepatitis C virus (HCV) infects over 170 million people worldwide. While interferon is currently the most used single agent therapy, this drug may result in a sustained loss of virus from the blood in only up to $15 \%$ of patients; new options for treatment are needed. With the release of ribavirin in North America and Europe, a viral clearance rate or 'cure' may be attained in up to $40 \%$ of patients. Developing successful antiviral therapy that prevents or delays the development of cirrhosis, liver failure and liver cancer as well as decreasing the demand for liver transplantation are clearly identified goals. Unfortunately, there is no complete in vitro model of HCV replication or translation. Due to the lack of an animal or cell culture model of HCV infection, in vitro translation screening systems to identify inhibitors of HCV protein translation are being evaluated by a large number of biotechnology companies. With advancing computer technology, high throughput screening processes are now possible and can be joined to specific in vitro model testing systems. Along with examining some of the information known about HCV therapy and the HCV genome, the present review discusses potential targets for new therapies and identifies therapeutic agents that are nearing clinical application

Key Words: Antiviral therapy, Hepatitis C, Hepatitis C virus helicase, Hepatitis $\mathrm{C}$ virus proteinases, Hepatitis $\mathrm{C}$ virus RNA polymerase, Interferon

\section{Tendances futures du traitement des patients atteints d'une infection chronique au virus de l'hépatite $\mathrm{C}$}

RÉSUMÉ : Le virus de l'hépatite $\mathrm{C}(\mathrm{HCV})$ aurait déjà contaminé plus de 170 millions de personnes dans le monde. Si l'interféron est à l'heure actuelle la monothérapie la plus utilisée, ce médicament pourrait n'entraîner l'élimination du virus que chez $15 \%$ des patients. Il nous faux sans contredit de nouvelles options thérapeutiques. Avec le lancement de la ribavirine en Amérique du Nord et en Europe, on peut noter un taux d'élimination virale ou de guérison chez jusqu'à $40 \%$ des patients. La mise au point d'un traitement antiviral efficace qui prévient ou retarde le développement de la cirrhose, de l'insuffisance hépatique et du cancer du foie, tout en diminuant les demandes de transplantation hépatique sont les objectifs clairement identifiés. Malheureusement, il n'existe aucun modèle in vitro complet de la réplication ou de la translation du HCV. Étant donné l'absence de modèles d'infection au HCV chez l'animal ou par la mise en culture de cellules, beaucoup de compagnies de biotechnologie sont à évaluer des systèmes de dépistage de translation in vitro afin d'identifier les inhibiteurs de la translation de la protéine du HCV. Grâce aux progrès des technologies informatisées, des procédés de dépistage de fort volume sont maintenant possibles et peuvent être adjoints à des systèmes de modèles in vitro de dépistage. La présente synthèse se penche sur les renseignements acquis sur le traitement du HCV et sur son génome, mentionne les cibles potentielles des nouvelles thérapeutiques et identifie les agents qui sont sur le point d'être appliqués en clinique.

\section{INTERFERON}

Interferon therapy forms the basis for the management of acute and chronic hepatitis $\mathrm{C}$ virus (HCV) infection. The use of interferon has been reviewed in detail in several reports (1-3). Major advances for the treatment of HCV infection include higher dose interferon therapy, daily therapy and combination therapy. The three interferons that are presently approved in the United States are interferon alfa-2b (Intron A, Schering Plough, New Jersey), interferon alfa-2a (Roferon-A,
Hoffman La Roche Laboratories, Basle, Switzerland) and consensus interferon ( $\mathrm{r}$-metIFN-Con 1 , Amgen, California). These interferons as well as interferon alpha-1n (Wellferon, Burroughs Wellcome, North Carolina) are approved in Canada and appear to be clinically equivalent.

Emerging data about $\mathrm{HCV}$ viral kinetics indicate that the viral replication half-time is approximately $3 \mathrm{~h}$, leading to studies that use dosing intervals of $24 \mathrm{~h}$ or less (4). Therapy with pegylated interferon, a new long acting form of inter-

Departments of Medicine and Transplantation, California Pacific Medical Center, San Francisco, California

Correspondence and reprints: Dr Robert G Gish, 2340 Clay Street, \#423, San Francisco, California 94115, USA. Telephone 415-202-1530, fax 415-474-8543,e-mail gishr@sutterhealth.org

Received for publication July 7, 1998. Accepted September 21, 1998 
feron, allows interferon to persist in the circulation and to affect continuously the HCV virus for three to five days. Preliminary data suggest that this pegylated interferon produces an equal or better response with fewer side effects at a once or twice weekly dosing.

\section{OTHER THERAPEUTIC CYTOKINES}

Thymus-derived products: Crude thymus extracts (Thymic Fractions $1402 \mathrm{~A}$ and Immunoplex 402A, Biotherapeutics, Wisconsin), thymosin fraction 5 and thymosin alpha-1 (Zadaxin, SciClone, California) are cytokines derived from immunologically active proteins found in the thymus gland. Notably, these thymus-derived proteins appear to modulate the progression and stabilization of chronic viral hepatitis $(5-12)$.

Thymosin alpha-1 is a naturally occurring immune-stimulating protein reportedly present in decreased amounts in the serum of patients chronically infected with hepatitis B virus (HBV) (13). Results of initial studies in animals and humans infected with HBV suggested that thymosin alpha-1 and thymosin factor 5 increased the rate of clearance of HBV DNA and the subsequent seroconversion from positive to negative for hepatitis B surface antigen (13-17). Results of a subsequent controlled trial did not demonstrate any statistically significant difference between thymosin alpha-1 and placebo at short term follow-up (18). Thymosin alpha-1 has been approved in Singapore, China and Italy for the treatment of patients with hepatitis B infection.

Results of a recently completed Italian study combining thymosin alpha-1 with interferon indicated that approximately $60 \%$ of patients lost HBV DNA and HBV e antigen (17). Trials combining these agents are currently underway in patients with chronic $\mathrm{HCV}$ infection to determine whether this combination of immune stimulation is more efficacious than interferon alone.

\section{NEW ANTIVIRAL THERAPY}

Ribavirin: Ribavirin (1-beta-D-ribofuranosyl-1,2,4-triazole-3-carboxamide) (Virazole, Viratek, ICN Pharmaceuticals, California and Rebetol, Schering Plough), a nucleoside analogue with a structure similar to that of azathioprine, is effective in the treatment of respiratory syncytial virus and Hanta virus infections. The mechanism of action of ribavirin against HCV has not been defined. Postulated antiviral effects based on events in other virus models include depletion of intracellular phosphate pools, inhibition of $5^{\prime}$ cap structure of viral mRNA, inhibition of viral-dependent RNA polymerases, and the possible immunomodulation effects of preserving $\mathrm{T}$ helper- 1 and reducing $T$ helper-2 effects $(19,20)$. Recent studies evaluated the use of ribavirin as a single agent for the treatment of chronic HCV infection (21-26). Among these studies, decreases in inflammation in the liver as well as a decrease in serum alanine aminotransferase levels were reported in a portion of patients. However, most patients on single agent therapy did not have a measurable decrease in their serum HCV RNA levels (22,23,25-31).
Because ribavirin therapy may modulate the immune system and act as an immune stimulant, there is a theoretical advantage to using this medication in combination with interferon and other cytokines $(19,20)$. When ribavirin and interferon alfa- $2 \mathrm{~b}$ were used together in one study, a $40 \%$ sustained response, as defined by long term clearance of HCV RNA, was reported, although the number of patients studied was small (32). Other studies using larger patient populations and including control groups in some trials have shown a significant level of efficacy (as judged by the sustained response rates that ranged from 30\% to 70\%) in clinically diverse patient populations (32-37). An extrapolation of the data in the available literature implies that the use of interferon alfa-2b with ribavirin (Rebetron, Schering Plough) appears to double or quadruple the sustained response rate obtained compared with that for interferon therapy alone. This result was evident in both patients who had never been treated with interferon as well as for patients who had relapsed after stopping an initial interferon treatment regimen $(38,39)$. Moreover, separate data also indicate that interferon therapy with ribavirin may be promising (24\% sustained response rate) for patients with recurrent HCV disease after liver transplantation (40).

\section{TARGETING FUNCTIONAL SITES IN THE HCV GENOME}

The HCV genome has been studied extensively over the past nine years (41). The data acquired have allowed the identification of various HCV protein products involved in viral replication, translation and packaging. Each active genomic site and its translation product is a potential target for antiviral therapy (Figure 1). The first step in the development of therapeutic agents is to identify antiviral compounds that can be taken orally so that they are delivered in an active state to hepatocytes, with the goal of remaining nontoxic while inhibiting viral replication. The use of one or more compounds now appears to be the likely means through which more effective therapy can be developed.

Ultimately, these newly identified single agents may not result in viral clearance or sustained response, that is, 'cure', when used alone. If used with cytokines such as interferon, these designed drugs may dramatically decrease the level of viral replication, viral mutation and genetic diversity, thereby, resulting in a much greater 'cure' rate. The lessons learned from the treatment of human immunodeficiency virus (HIV) infection with combination therapy will probably be applicable to HCV therapy. It is likely that clinicians will be using a combination of antiviral therapies to treat the estimated five to six million patients in Canada and the United States, as well as the 170 million HCV-infected persons worldwide. However, an important difference between HIV and HCV infection is that interferon is believed to result in complete HCV eradication in a subset of individuals.

The HCV RNA-dependent RNA polymerase is responsible for the replication of the entire HCV genome (41). Ideally, drugs targeting this enzyme need to be nucleotide or nucleoside analogues that act at the enzyme's active site. To 


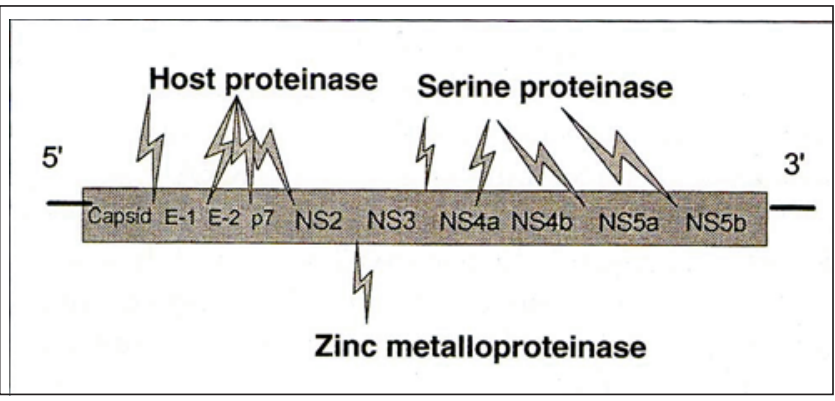

Figure 1) Hepatitis $\mathrm{C}$ genome. Hepatitis $\mathrm{C}$ genomic sites and their translation products are potential targets (proteinase cleavage sites) for anti-hepatitis $\mathrm{C}$ virus drug therapy (lightening bolts). The internal ribosomal entry site at the $5^{\prime}$ noncoding region stimulates polyprotein translation and is a good target because of its three-dimensional structure because it is highly conserved across all genotypes. At the capsid area, increased inhibition of tumour necrosis factor dimer stops apoptosis. Host-derived proteinases start hepatits $\mathrm{C}$ virus ( $\mathrm{HCV}$ ) protein cleavage from core-envelope 1 (E1) to NS2-3. Zinc metalloproteinase acts at the NS2 site. Drugs may be developed to inhibit the multiple HCV serine proteinases acting along segments NS3 to NS5b. At NS3, the potential targets are the RNA binding site and helicase binding site. Stabilizing proteinases and proteinase cofactors are potential targets in the NS4a regions. The proposed interferon sensitivity-determining region described by Japanese research (56) but not confirmed elsewhere is within NS5a. This region may be involved in interferon resistance. For the NS5b region, RNA-dependent RNA polymerase inhibitors may provide another method of inhibiting viral replication

this end, $x$-ray crystallographic data have identified the three-dimensional structure of the RNA polymerase, allowing drug design to move forward (42). By blocking the replication of the complete viral genome, mutation rates may also be decreased, and the 'escape' of the mutant virus from immune surveillance may occur less often. In addition, the production of proteinases that are required for the generation of smaller viral protein products will be decreased, resulting in a fall in the production of complete viral particles.

Although $\mathrm{HCV}$ is a single $(+)$ stranded virus, specific areas of the viral genome interact with each other to form a complex structure that requires denaturation for genetic replication and protein translation to take place (41). The HCV helicase enzyme (Figure 2) is derived from the carboxyl end of the NS3 region and is involved in the "unwinding' or unfolding of the HCV RNA quaternary structure $(40,42-48)$. The structure and active functional areas of the helicase enzyme have been described by researchers and are now the areas of intensive study aimed at drug development.

The structure, function and products of the HCV proteinases have been defined by a number of investigators $(41,50$ 54). Accordingly, proteolytic processing begins with the host-derived proteinases cleaving the HCV proteins between the core-envelope 1 (E-1) regions, the E-1 and E-2 region, and the E-2 and NS2 segments, with added autoproteolytic cleavage occurring between the NS2 and NS3 sequences. The subsequently produced NS3 protein is then complexed with protein product NS4a, and together they cleave at the NS3-4a, NS4a-4b, NS4b-5a and NS5a-5b junctions.

Because directed proteolytic processing is crucial for $\mathrm{HCV}$ production and maturation, zinc metalloproteinase

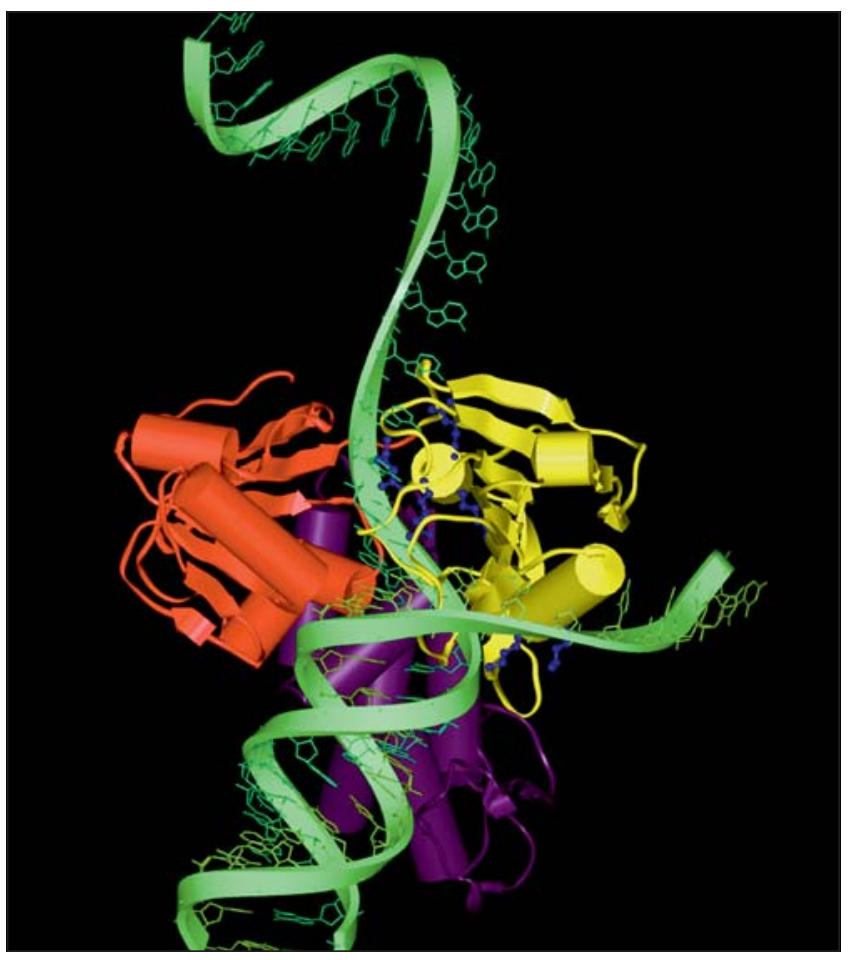

Figure 2) The three-dimensional structure of hepatitis $C$ virus helicase with unfolding of an RNA molecule

and serine proteinase enzymes have been implicated among the most likely targets for immediate anti-HCV drug development. However, because multiple proteins in the coagulation pathway are serine proteinases, great care is needed during drug design and development to ensure that drugs designed to inhibit HCV proteinases do not induce hyper- and hypocoagulable states. In addition, leukocyte elastase is another natural proteinase that may interact with HCV proteinase inhibitors, possibly obviating drug function and/or interfering with normal leukocyte activity. New methods for screening potential proteinase inhibitors are also being developed (55), and it is important to note that experience with the development of proteinase inhibitors has resulted in the availability of HIV proteinase inhibitors (aspartate proteinase), trypsin inhibitors, thrombin inhibitors and angiotensin-converting enzyme inhibitors.

The internal ribosomal entry site (IRES), located at the $5^{\prime}$ noncoding region of the HCV genome, is another potential site suitable for antiviral drug development. HCV translation involves the production of a single contiguous polyprotein product (Figure 1). The IRES region directs the polyprotein production, which is cap-independent, and requires complete ribosomal assembly. The blockage or inhibition of IRES-mediated translation would stop the production of all viral proteins because binding of the $40 \mathrm{~S}$ ribosomal subunit is essential for the translation of the viral genome.

The interferon sensitivity-determining region is a postulated area in the NS5a region of the HCV genome that may 'program' interferon resistance when mutations occur (Figure 1) (56). These mutations appear to lead to the pro- 
duction of a protein product that represses the action of the protein kinase RNA-activated (PKR) gene product. The proper function of this PKR protein is a key aspect of the therapeutic intracellular events initiated by interferon (57-60). Thus, agents that block the repression of the PKR protein appear to be potential candidates as new therapeutic agents to be used alone or with interferon, yet further study is warranted.

Despite the promise of these proteinase, helicase and RNA-dependent RNA polymerase inhibitors, development of these agents is slowed by the lack of a suitable cell culture or animal model. In addition, drug selection with high throughput methodologies is necessary and will undoubtedly be enhanced after one or two model inhibitors are developed. The large open cleft in the serine proteinase molecule also makes drug design difficult due to the poor binding characteristics of the active site to new medications. Can available drugs be used, or must a new class of medications be designed? Given the various genomic loci available as potentially therapeutic sites, current advances in biotechnology are pointing towards new ways to stop $\mathrm{HCV}$ replication. The following is a discussion of the most biologically plausible approaches designed to block viral replication.

\section{NEW METHODS OF INTERFERING WITH VIRAL REPLICATION}

Antisense oligonucleotides: Antisense molecules are targeted to a complementary sequence of viral RNA. The binding of an antisense RNA molecule blocks translation by hybrid arrest of the translational machinery or by the induction of ribonuclease (RNAase) activity that results in the cleavage of the double-stranded RNA portion of the hybrid. The attachment of these complementary RNA sequences blocks the binding of ribosomes to the viral RNA, inhibiting subsequent assembly of amino acids into viral proteins. These oligonucleotide sequences may be a powerful tool to stop viral replication without the use of potentially toxic nucleoside analogues used to block transcription of the HCV genome. An in vitro model of $\mathrm{HCV}$ translation has shown the ability of antisense oligonucleotides to inhibit HCV translation $(61,62)$. Wakita et al $(62)$ quantified the level of inhibition by using nucleotides complementary to a segment of the HCV genotype $1 \mathrm{~b}$ genome that were attached to the firefly luciferase reporter gene. Drug delivery and the nonspecific nature of antisense strategies will limit the application of this technology for the near future.

Ribozymes and nonfunctioning ribozymes: Ribozymes are catalytic RNA molecules that serve as enzymes able to break RNA molecules at specific sites (63-65). Ribozymes designed for specific sites in the HCV genome may lead to decreased viral protein production. Alternatively, false or nonfunctional ribozymes can be delivered or synthesized in hepatocytes. The presence of these nonfunctioning ribozymes results in the inhibition of the protein synthesis required for viral replication, packaging and release.

One ribozyme system named the 'hammerhead' system contains flanking nucleotides in the head region that attach to key sites in the HBV RNA replication intermediate and allow specific cleavage. A recent study using these hammerhead ribozymes directed at the $5^{\prime}$ noncoding region of $\mathrm{HCV}$ demonstrated direct inhibition of viral RNA translation (66). Further development in this area will require improved delivery techniques in humans to allow entry of these molecules into intact hepatocytes. However, drug delivery of any protein through other than parenteral routes remains a major clinical challenge.

Vaccines: Vaccine therapy for hepatitis viruses may be directed at stimulating a $T$ cell response rather than at $B$ cell antibody production as is used for most viral vaccines because antibodies appear not to be protective and are not able to prevent chronic infection. Chimpanzee models have not shown that vaccines can protect animals from subsequent inoculations of HCV virus of the same or similar genotypes (67). Yet, the need for effective vaccines is clear given the high infection rates among populations at risk of disease. Thus, a phase I clinical trial of an HCV vaccine has been completed in the United States (personal communication); the results of the trial and the initiation of a phase II trial are pending.

DNA-based vaccines: DNA-based vaccines are an innovative technique in the treatment of chronic viral infections $(68,69)$. An example of a model HBV DNA-based vaccine includes a plasmid containing a designed DNA gene fragment attached to a cytomegalovirus promoter intended for injection into muscle tissue. Once in the muscle, transcription of the DNA fragment takes place and results in the translation of a specified viral protein. The viral protein is taken into antigen-presenting cells and is expressed, with class-I molecules, to lymphocytes, resulting in a cytotoxic $\mathrm{T}$ cell response. Class-II expression with viral protein also results in a $\mathrm{B}$ cell response, thereby producing antibody directed at the viral protein. To date, pre-S-1 and pre-S-2 sequences from HBV have been used in an in vivo model, with results suggesting an enhanced immune response directed at HBV. This technology may be applicable to the treatment of chronic or acute HCV infection as well.

Dominant negative viral mutants: Genetic suppresser elements are cDNA sequences that encode antisense RNA and may be applied to the treatment of hepatitis infections by targeting key genetic sequences essential for viral replication or packaging (70). Preliminary studies of retroviruses in in vitro systems have been promising $(71,72)$. Specially created viral mutants may be designed to interfere with the assembly of the HBV nucleocapsid, causing the termination of viral replication. Theoretically, the carboxyl terminus of a truncated core protein (required for DNA binding) could be fused with the surface (S)-gene of HBV and mixed with wild type virus. Treatment could be initiated by using adenovirus-mediated transfection of this construct. The resulting transfected material would putatively block further transcription by binding to the targeted gene sequence. The HCV genome is a likely target of such therapy.

Immune globulin: There is evidence that up to $15 \%$ of individuals who become infected with HCV clear the virus through internal immune processes. HCV has the ability to 
undergo rapid genetic changes that aid HCV survival by allowing an ongoing escape from both B (immune globulin production) and $\mathrm{T}$ cell immune surveillance, and recognition. HCV antibodies have been suggested to form a passive or active immune response, but, most commonly, they appear to be a paraphenomenon indicating active infection in most instances or occasional passive exposure to antibodies in other cases $(67,73-78)$. Supporting the concept that immune globulins modulate HCV infection, recent information suggests that there is an increase in the transmission of $\mathrm{HCV}$ when immune globulin preparations are administered after screening for the presence of HCV antibody (78). Immune globulin therapy is not recommended as part of postexposure prophylaxis. The development of monoclonal antibodies directed at HCV may be useful as part of combination antiviral therapy or may be useful in acute exposure, but conserved viral proteins across genotypes and quasispecies must be identified. Alternatively, a mixture of monoclonal antibodies may be useful to modulate disease and to act as an adjunct to direct antiviral therapy.

\section{CONCLUSIONS}

The treatment of HCV infection is rapidly evolving. The addition of knowledge about the genetic structure and function of the HCV genome is allowing researchers to explore new possible targets for therapy. Moreover, rapidly advancing technologies are yielding more effective ways to develop new drugs and to minimize viral replication. Within five to 10 years, a cure is conceivable in $50 \%$ to $80 \%$ of individuals infected with $\mathrm{HCV}$, and vaccines may prevent or abrogate most infections.

ACKNOWLEDGEMENTS: The authors thank Dr Nanhua Yao at Schering Plough Research Institute, Kenilworth, New Jersey, for the use of the three-dimensional image of the hepatitis $\mathrm{C}$ virus helicase enzyme structure. Schering Plough provided an unrestricted educational grant for the Conference on Hepatitis C Virus Therapies as part of the Canadian Digestive Disease Week, February 1998 from which this article was derived.

\section{REFERENCES}

1. National Institutes of Health Consensus Development Conference Panel statement: management of hepatitis C. Hepatology 1997;26:2S-10S.

2. Alter MJ. Epidemiology of hepatitis C. Hepatology 1997;26:62S-5S.

3. Carithers RLJ, Emerson SS. Therapy of hepatitis C: meta-analysis of interferon alfa-2b trials. Hepatology 1997;26:83S-8S.

4. Lam NP, Neumann AU, Gretch DR, Wiley TE, Perelson AS, Layden TJ. Dose-dependent acute clearance of hepatitis $\mathrm{C}$ genotype 1 virus with interferon alfa. Hepatology 1997;26:226-31.

5. Cianciara J, Laskus $T$. Thymic factor $X$ treatment of chronic hepatitis B. Hepatology 1992;16:1507-8.

6. Dworniak D, Tchorzewski H, Pokoca L, et al. Treatment with thymic extract TFX for chronic active hepatitis B. Arch Immunol Ther Exp (Warsz) 1991;39:537-47.

7. Fattovich G, Giustina G, Alberti A, et al. A randomized controlled trial of thymopentin therapy in patients with chronic hepatitis B. J Hepatol 1994;21:361-6.

8. Galli M, Crocchiolo P, Negri C, Caredda F, Lazzarin A, Moroni M. Attempt to treat acute type B hepatitis with an orally administered thymic extract (thymomodulin): preliminary results. Drugs Exp Clin Res 1985;11:665-9.
9. Mutchnick MG, Ehrinpreis MN, Kinzie JL, Peleman RR. Prospectives on the treatment of chronic hepatitis B and chronic hepatitis $\mathrm{C}$ with thymic peptides and antiviral agents. Antiviral Res 1994;24:245-57.

10. Romeo F, Arcoria D, Palmisano L, Polosa P. Effectiveness of thymostimulin treatment in hepatitis $\mathrm{B}$ surface antigen-positive chronic active liver disease. Results of a randomized clinical trial. Arzneimittelforschung 1985;35:1317-22.

11. Romeo F, Palmisano L, Arcoria D. Thymostimulin in the treatment of hepatitis B surface antigen-positive chronic active hepatitis. Controlled clinical trial - two years follow-up. Arzneimittelforschung 1987;37:450-6.

12. Zaruba K, Rastorfer M, Grob PJ, Joller-Jemelka H, Bolla K. Thymopentin as adjuvant in non-responders or hyporesponders to hepatitis B vaccination. Lancet 1983;ii:1245-5.

13. Eichberg JW, Seeff LB, Lawlor DL, et al. Effect of thymosin immunostimulation with and without corticosteroid immunosuppression on chimpanzee hepatitis B carriers. J Med Virol 1987;21:25-37.

14. Andreone P, Cursaro C, Gramenzi A, et al. A randomized controlled trial of thymosin-alphal versus interferon alfa treatment in patients with hepatitis B e antigen antibody - and hepatitis B virus DNA positive chronic hepatitis B. Hepatology 1996;24:774-7.

15. Davis GL. Treatment of chronic hepatitis B. Hepatology 1991;14:567-9.

16. Mutchnick MG, Appelman HD, Chung HT, et al. Thymosin treatment of chronic hepatitis B: a placebo-controlled pilot trial. Hepatology 1991;14:409-15.

17. Rasi G, DiVirgilio D, Mutchnick MG, et al. Combination thymosin alpha 1 and lymphoblastoid interferon treatment in chronic hepatitis C. Gut 1996;39:679-83.

18. Mutchnick MG, Lindsay KL, SchiffER, Cummings GD, Appelman HD. Thymosin $\alpha-1$ treatment of chronic hepatitis B: a multicenter randomized, placebo-controlled double blind study. Gastroenterology 1995;108:a1127. (Abst)

19. Ning Q, Brown D, Parodo J, et al. Ribavirin inhibits viral-induced macrophage production of TNF, IL-1, the procoagulant fgl2 prothrombinase and preserves Th1 cytokine production but inhibits Th2 cytokine response. J Immunol 1998;160:3487-93.

20. White DO. Antiviral chemotherapy. Med J Aust 1984;140:715-20.

21. Acero D, Adrados M, González-Huix F, Figa M. Ribavirin treatment in patients with chronic hepatitis $\mathrm{C}$ refractory to interferon-alpha. Gastroenterol Hepatol 1996;19:243-6.

22. Bodenheimer HCJ, Lindsay KL, Davis GL, Lewis JH, Thung SN, Seeff LB. Tolerance and efficacy of oral ribavirin treatment of chronic hepatitis C: a multicenter trial. Hepatology 1997;26:473-7.

23. Camps J, Garcia N, Riezu-Boj JI, Civeira MP, Prieto J. Ribavirin in the treatment of chronic hepatitis $\mathrm{C}$ unresponsive to alfa interferon. J Hepatol 1993;19:408-12.

24. Di Bisceglie AM, Conjeevaram HS, Fried MW, et al. Ribavirin as therapy for chronic hepatitis C. A randomized, double-blind, placebo-controlled trial. Ann Intern Med 1995;123:897-903.

25. Di Bisceglie AM, Shindo M, Fong TL, et al. A pilot study of ribavirin therapy for chronic hepatitis C. Hepatology 1992;16:649-54.

26. Dusheiko G, Main J, Thomas H, et al. Ribavirin treatment for patients with chronic hepatitis C: results of a placebo-controlled study. J Hepatol 1996;25:591-8.

27. Fried MW, Hoofnagle JH. Therapy of hepatitis C. Semin Liver Dis 1995;15:82-91.

28. Koskinas J, Tibbs C, Saleh MG, Pereira LM, McFarlane IG, Williams R. Effects of ribavirin on intrahepatic and extrahepatic expression of hepatitis $\mathrm{C}$ virus in interferon nonresponsive patients. J Med Virol 1995;45:29-34.

29. Reichard O, Andersson J, Schvarcz R, Weiland O. Ribavirin treatment for chronic hepatitis C. Lancet 1991;337:1058-61.

30. Reichard O, Yun ZB, Sonnerborg A, Weiland O. Hepatitis C viral RNA titers in serum prior to, during, and after oral treatment with ribavirin for chronic hepatitis C. J Med Virol 1993;41:99-102.

31. Schvarcz R, Yun ZB, Sonnerborg A, Weiland O. Combined treatment with interferon alpha-2b and ribavirin for chronic hepatitis $\mathrm{C}$ in patients with a previous non-response or non-sustained response to interferon alone. J Med Virol 1995;46:43-7.

32. Brillanti S, Garson J, Foli M, et al. A pilot study of combination therapy with ribavirin plus interferon alfa for interferon alfa-resistant chronic hepatitis C. Gastroenterology 1994;107:812-7.

33. Lai MY, Kao JH, Yang PM, et al. Long-term efficacy of ribavirin plus 
interferon alfa in the treatment of chronic hepatitis C. Gastroenterology 1996;111:1307-12.

34. Reichard O, Norkrans G, Fryden A, Braconier JH, Sonnerborg A, Weiland O. Randomised, double-blind, placebo-controlled trial of interferon alpha-2b with and without ribavirin for chronic hepatitis C. The Swedish Study Group. Lancet 1998;351:83-7.

35. Reichard O, Schvarcz R, Weiland O. Therapy of hepatitis C: alpha interferon and ribavirin. Hepatology 1997;26:108S-11S.

36. Schalm SW, Brouwer JT, Chemello L, et al. Interferon-ribavirin combination therapy for chronic hepatitis C. Dig Dis Sci 1996;41:131S-4S.

37. Schalm SW, Hansen BE, Chemello L, et al. Ribavirin enhances the efficacy but not the adverse effects of interferon in chronic hepatitis C. Meta-analysis of individual patient data from European centers. J Hepatol 1997;26:961-6.

38. Davis GL, Esteban-Mur R, Rustgi V, et al. Interferon alfa-2b alone or in combination with ribavirin for the treatment of relapse of chronic hepatitis C. International Hepatitis Interventional Therapy Group. N Engl J Med 1998;339:1493-9.

39. McHutchison JG, Gordon SC, Schiff ER, et al. Interferon alfa-2b alone or in combination with ribavirin as initial treatment for chronic hepatitis C. Hepatitis Interventional Therapy Group. N Engl J Med 1998;339:1485-92.

40. Bizollon T, Palazzo U, Ducerf C, et al. Pilot study of the combination of interferon alfa and ribavirin as therapy of recurrent hepatitis $\mathrm{C}$ after liver transplantation. Hepatology 1997;26:500-4.

41. Major ME, Feinstone SM. The molecular virology of hepatitis C. Hepatology 1997;25:1527-38.

42. Behrens SE, Tomei L, De Francesco R. Identification and properties of the RNA-dependent RNA polymerase of hepatitis $\mathrm{C}$ virus. EMBO J 1998;15:12-22.

43. Gwack Y, Kim DW, Han JH, Choe J. Characterization of RNA binding activity and RNA helicase activity of the hepatitis $\mathrm{C}$ virus NS3 protein. Biochem Biophys Res Commun 1996;225:654-9.

44. Gwack Y, Kim DW, Han JH, Choe J. DNA helicase activity of the hepatitis $\mathrm{C}$ virus nonstructural protein 3. Eur J Biochem 1997;250:47-54.

45. Hong Z, Ferrari E, Wright-Minogue J, et al. Enzymatic characterization of hepatitis $\mathrm{C}$ virus NS3/4A complexes expressed in mammalian cells by using the herpes simplex virus amplicon system. J Virol 1996;70:4261-8.

46. Kim DW, Gwack Y, Han JH, Choe J. C-terminal domain of the hepatitis C virus NS3 protein contains an RNA helicase activity. Biochem Biophys Res Commun 1995;215:160-6.

47. Kim DW, Gwack Y, Han JH, Choe J. Towards defining a minimal functional domain for NTPase and RNA helicase activities of the hepatitis C virus NS3 protein. Virus Res 1997;49:17-25.

48. Kim DW, Kim J, Gwack Y, Han JH, Choe J. Mutational analysis of the hepatitis C virus RNA helicase. J Virol 1997;71:9400-9.

49. Yao N, Hesson T, Cable M, et al. Structure of the hepatitis C virus RNA helicase domain. Nat Struct Biol 1997;4:463-7.

50. Hirowatari Y, Hijikata M, Shimotohno K. A novel method for analysis of viral proteinase activity encoded by hepatitis $C$ virus in cultured cells. Anal Biochem 1995;225:113-20.

51. Hirowatari Y, Hijikata M, Tanji Y, Shimotohno K. Expression and processing of putative nonstructural proteins of hepatitis $\mathrm{C}$ virus in insect cells using baculovirus vector. Virus Res 1995;35:43-61.

52. Kakiuchi N, Hijikata M, Komoda Y, Tanji Y, Hirowatari Y, Shimotohno K. Bacterial expression and analysis of cleavage activity of HCV serine proteinase using recombinant and synthetic substrate. Biochem Biophys Res Commun 1995;210:1059-65.

53. Kakiuchi N, Komoda Y, Hijikata M, Shimotohno K. Cleavage activity of hepatitis $\mathrm{C}$ virus serine proteinase. J Biochem (Tokyo ) 1997;122:749-55.

54. Shimotohno K, Tanji Y, Hirowatari Y, Komoda Y, Kato N, Hijikata M. Processing of the hepatitis $C$ virus precursor protein. J Hepatol 1995;22:87-92.

55. Feller JA, Carroll AR, Sangar DV, Lau JYN, Clarke BE. Expression of enzymatically active HCV NS3 protease (genotype 1b) and the development of an in-vitro protease assay system. Hepatology 1995;22:A897. (Abst)

56. Chayama K, Tsubota A, Kobayashi M, et al. Pretreatment virus load and multiple amino acid substitutions in the interferon sensitivity-determining region predict the outcome of interferon treatment in patients with chronic genotype $1 \mathrm{~b}$ hepatitis $\mathrm{C}$ virus infection. Hepatology 1997;25:745-9.

57. Enomoto N, Sakuma I, Asahina Y, et al. Comparison of full-length sequences of interferon-sensitive and resistant hepatitis $C$ virus $1 \mathrm{~b}$. Sensitivity to interferon is conferred by amino acid substitutions in the NS5A region. J Clin Invest 1995;96:224-30.

58. Enomoto N, Sakuma I, Asahina Y, et al. Mutations in the nonstructural protein $5 \mathrm{~A}$ gene and response to interferon in patients with chronic hepatitis $C$ virus $1 b$ infection. $N$ Engl J Med 1996;334:77-81.

59. Kurosaki M, Enomoto N, Murakami T, et al. Analysis of genotypes and amino acid residues 2209 to 2248 of the NS5A region of hepatitis $\mathrm{C}$ virus in relation to the response to interferon-beta therapy. Hepatology 1997;25:750-3.

60. Sato C, Enomoto N. Specific hepatitis C virus NS5A sequences determine the outcome of interferon treatment. Gastroenterology 1996;111:1152-4.

61. Alt M, Renz R, Hofschneider PH, Paumgartner G, Caselmann WH. Specific inhibition of hepatitis $\mathrm{C}$ viral gene expression by antisense phosphorothioate oligodeoxynucleotides. Hepatology 1995;22:707-7.

62. Wakita T, Wands JR. Specific inhibition of hepatitis C virus expression by antisense oligodeoxynucleotides. In vitro model for selection of target sequence. J Biol Chem 1994;269:14205-10.

63. Branch AD, Robertson HD. Efficient trans cleavage and a common structural motif for the ribozymes of the human hepatitis delta agent. Proc Natl Acad Sci USA 1991;88:10163-7.

64. Offensperger WB, Blum HE, Gerok W. Molecular therapeutic strategies in hepatitis B virus infection. Clin Invest 1994;72:737-41.

65. Prasad Y, Smith JB, Gottlieb PA, Bentz J, Dinter-Gottlieb G. Deriving a 67-nucleotide trans-cleaving ribozyme from the hepatitis delta virus antigenomic RNA. Antisense Res Dev 1992;2:267-77.

66. Sakamoto N, Wu CH, Wu GY. Inhibition of hepatitis C virus-directed translation by hammerhead ribozymes in-vitro. Hepatology 1995;22:A896. (Abst)

67. Farci P, Alter HJ, Govindarajan S, et al. Lack of protective immunity against reinfection with hepatitis $C$ virus. Science 1992;258:135-40.

68. Michel ML, Davis HL, Schleef M, Mancini M, Tiollais P, Whalen RG. DNA-mediated immunization to the hepatitis B surface antigen in mice: aspects of the humoral response mimic hepatitis B viral infection in humans. Proc Natl Acad Sci USA 1995;92:5307-11.

69. Tokushige K, Wakita T, Pachuk C, et al. Expression and immune response to hepatitis $\mathrm{C}$ virus core $\mathrm{DNA}$ - based vaccine constructs. Hepatology 1996;24:14-20.

70. Holzmayer TA, Pestov DG, Roninson IB. Isolation of dominant negative mutants and inhibitory antisense RNA sequences by expression selection of random DNA fragments. Nucleic Acids Res 1992;20:711-7.

71. Endres CL, Bergquam EP, Axthelm MK, Wong SW. Suppression of simian immunodeficiency virus replication by human immunodeficiency virus type 1 trans-dominant negative rev mutants. J Virol 1995;69:5164-6.

72. Weber PC, Wigdahl B. Identification of dominant-negative mutants of the herpes simplex virus type 1 immediate-early protein ICPO. J Virol 1992;66:2261-7.

73. Daugherty D. Genetic structure and heterogeneity of hepatitis $\mathrm{C}$ virus: a vaccine impediment? Hepatology 1992;15:739-41.

74. Farci P, Alter HJ, Wong DC, et al. Prevention of hepatitis C virus infection in chimpanzees after antibody-mediated in vitro neutralization. Proc Natl Acad Sci USA 1994;91:7792-6.

75. Farci P, Shimoda A, Wong D, et al. Prevention of hepatitis C virus infection in chimpanzees by hyperimmune serum against the hypervariable region 1 of the envelope 2 protein. Proc Natl Acad Sci USA 1996;93:15394-9.

76. Piazza M, Sagliocca L, Tosone G, et al. Sexual transmission of the hepatitis $\mathrm{C}$ virus and efficacy of prophylaxis with intramuscular immune serum globulin. A randomized controlled trial. Arch Intern Med 1997;157:1537-44.

77. Purcell R. The hepatitis C virus: overview. Hepatology 1997;26:11S-4S.

78. Shimizu YK, Igarashi H, Kiyohara T, et al. A hyperimmune serum against a synthetic peptide corresponding to the hypervariable region 1 of hepatitis $\mathrm{C}$ virus can prevent viral infection in cell cultures. Virology 1996;223:409-12. 


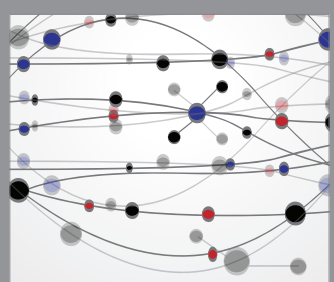

The Scientific World Journal
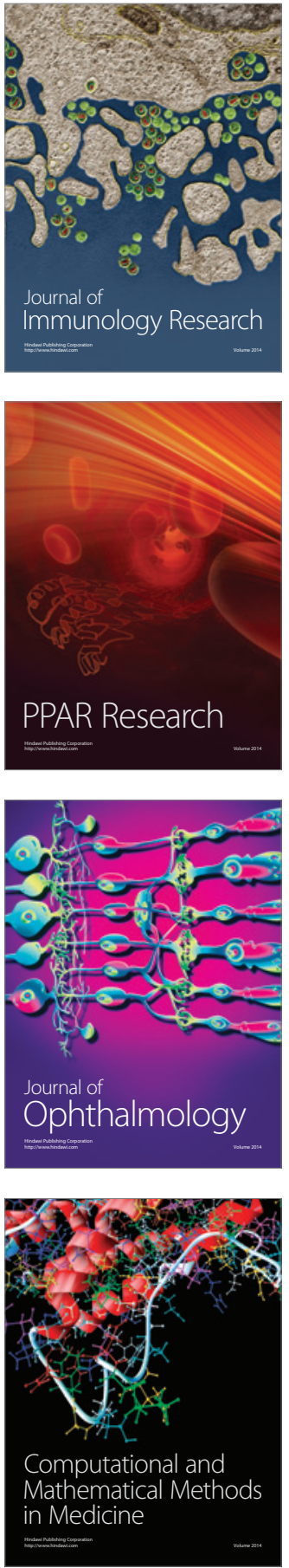

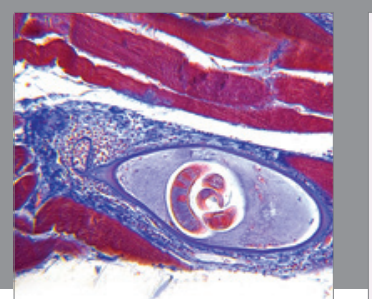

Gastroenterology Research and Practice

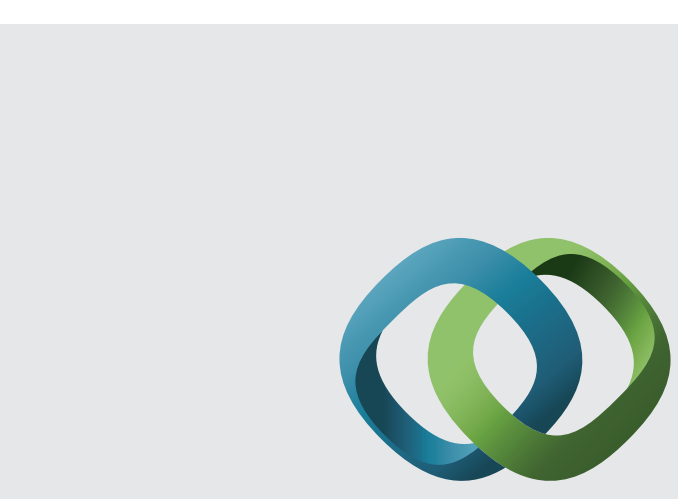

\section{Hindawi}

Submit your manuscripts at

http://www.hindawi.com
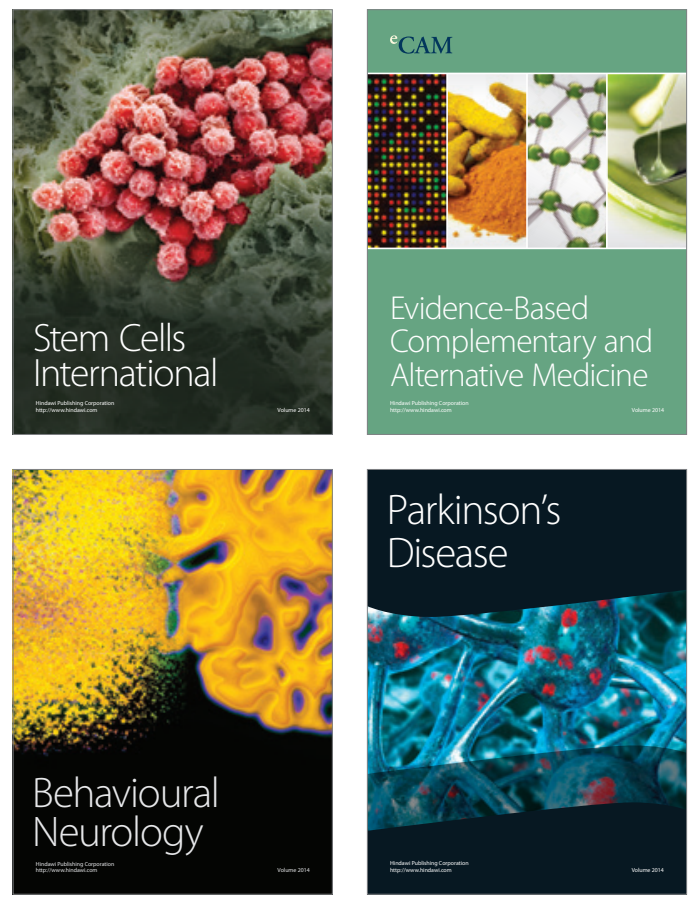
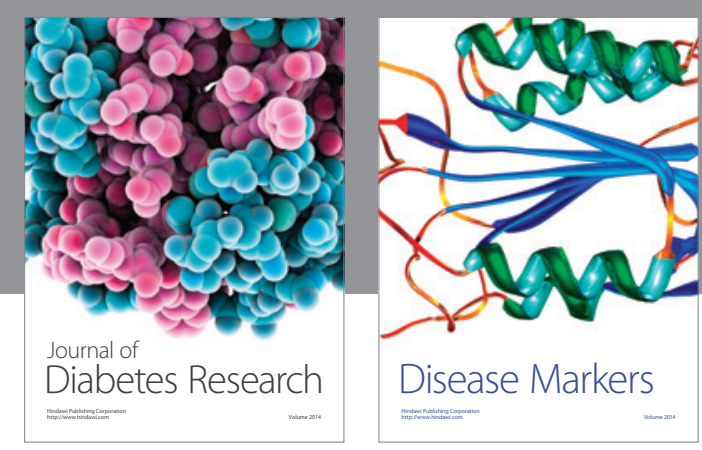

Disease Markers
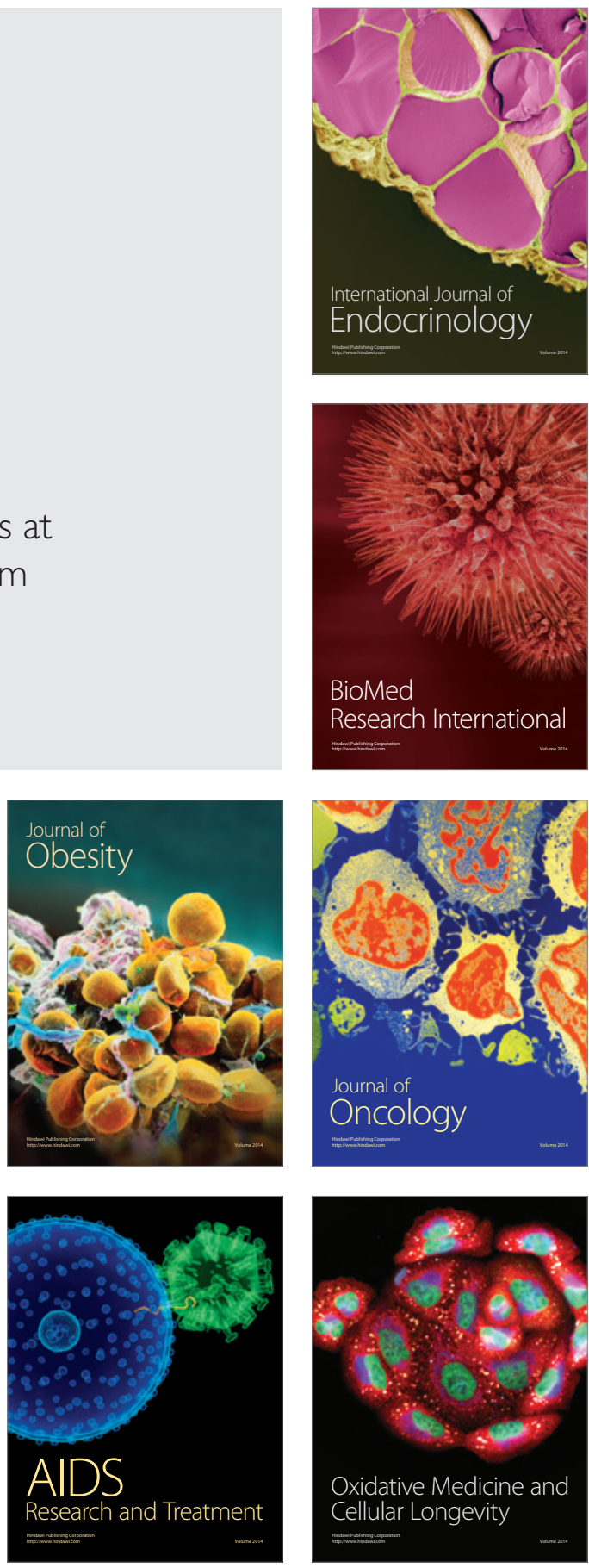